Фармацевтична технологія, біофармація, гомеопатія Pharmaceutical technology, biopharmacy, homeopathy

УДК 615.263:546.56/.59

DOI https://doi.org/10.11603/2312-0967.2018.4.9685

\title{
ДОСЛІДЖЕННЯ 3 РОЗРОБКИ КОСМЕТИЧНИХ ЗАСОБІВ НА ОСНОВІ НАНОЧАСТИНОК СРІБЛА, ЗОЛОТА І МІДІ
}

\author{
() С. Б. Білоус ${ }^{1}$, С. М. Дибкова ${ }^{2,3}$, Л. С. Рєзніченко
}

\author{
Львівський національний медичний університет імені Данила Галицького ${ }^{1}$ \\ Інститут біоколоїдної хімії імені Ф. Д. Овчаренка НАН України ${ }^{2}$ \\ Інститут ветеринарної медицини НААН України ${ }^{3}$ \\ svitlana.bilous@gmail.com
}

\begin{abstract}
Мета роботи. Обґрунтувати склад і технологію перспективних косметичних засобів із наночастинками срібла, золота і міді.

Матеріали і методи. Для розробки косметичних засобів використовували колоїдні розчини наночастинок срібла, золота і міді, синтезовані в Інституті біоколоїдної хімії імені Ф. Д. Овчаренка НАН України. Антимікробну активність колоїдних розчинів наночастинок металів у дослідженнях in vitro визначали методом серійних розведень в агарі. Безпечність колоїдних розчинів наночастинок срібла, золота і міді визначали в тестах in vitro за показниками цитотоксичності, генотоксичності, мутагенності, імунотоксичності та біохімічними маркерами. Для обґрунтування складу і технології косметичних засобів використано методи інорормаційного пошуку, аналізу даних літератури та технологічні дослідження.

Результати й обговорення. Результати щодо антимікробної активності колоїдних розчинів наночастинок металів показали, що наночастинки срібла і міді проявляють виражену бактерицидну дію, а наночастинки золота - слабку антимікробну активність. Дослідження рівня безпеки досліджених наночастинок свідчать про безпечність і доцільність їх подальшого медико-біологічного використання.

Враховуючи особливості вимог до впровадження на ринок косметичних засобів, порівняно з лікарськими, зокрема відсутність обов'язкових вимог до проведення якісного та кількісного аналізу наночастинок у косметичному засобі, а лише необхідність проведення санітарно-гігієнічної експертизи, визначено перспективи наночастинок металів як біологічно активних компонентів косметичних засобів. Обґрунтовано склад і технологію гелю для догляду за жирною шкірою, у якому як активні компоненти використано розчин наночастинок міді та олію амаранту, крему для догляду за старіючою шкірою з наночастинками золота та бальзаму для губ з антигерпетичною дією на основі наночастинок срібла і золота.

Висновки. Результати дослідження свідчать про перспективність подальших досліджень косметичних засобів на основі наночастинок металів, що буде сприяти розширенню номенклатури інноваційних косметичних засобів.
\end{abstract}

Ключові слова: косметичні засоби; наночастинки срібла; наночастинки золота; наночастинки міді.

Вступ. Враховуючи унікальні фрізико-хімічні характеристики, високу біологічну активність наночастинок золота, срібла та міді [1, 2, 3], а також особливості вимог до впровадження на ринок косметичних засобів порівнянно з лікарськими, зокрема відсутність обов'язкових вимог до проведення якісного та кількісного аналізу наночастинок у косметичному засобі, а лише необхідність проведення санітарно-гігієнічної експертизи, наночастинки металів перспективні як біологічно активні компоненти косметичних засобів.

Застосування наночастинок металів із передбаченим терапевтичним потенціалом, які водночас всебічно охарактеризовані за фрізико-хімічними параметрами та маркерами безпечності, дасть змогу запропонувати споживачам новий клас високоефективних косметичних засобів.

Матеріали і методи. Для розробки косметичних засобів використовували колоїдні розчини наночас- тинок срібла ( $\left.\mathrm{C}_{\mathrm{Ag}}=8,0 \mathrm{мг} / \mathrm{M} л\right)$, золота $\left(\mathrm{C}_{\mathrm{Au}}=0,15 \mathrm{мг} / \mathrm{M} л\right)$ і міді $\left(\mathrm{C}_{\mathrm{Cu}}=32,0 \mathrm{Mr} / \mathrm{Mл}\right)$, синтезовані в Інституті біоколоїдної хімії імені Ф. Д. Овчаренка НАН України методом хімічної конденсації у водному розчині за оригінальними протоколами. Відповідно до даних електронно-мікроскопічних досліджень (трансмісійний електронний мікроскоп JEM-1230, «JEOL», Японія) синтезовані наночастинки мали сореричну фрорму. Середній розмір частинок золота і срібла становив 30 нм, міді - 20 нм. За даними рентгенструктурного мікроаналізу у складі наночастинок фріксувався лише вміст відповідного металу.

Антимікробну активність колоїдних розчинів наночастинок металів у дослідженнях in vitro визначали методом серійних розведень в агарі згідно з методичними вказівками «Визначення чутливості мікроорганізмів до антибактеріальних препаратів», затвердженими наказом МОЗ України № 167 від 05.04.2007 р.

ISSN 2312-0967. Pharmaceutical review. 2018. № 4 
Фармацевтична технологія, біофармація, гомеопатія Pharmaceutical technology, biopharmacy, homeopathy

Як тестові культури використовували штами мікроорганізмів Staphylococcus aureus 209P, Escherichia coli № 25, Pseudomonas aeruginosa ATCC 27853 (F-51), Candida albicans, Proteus vulgaris HX 19 № 222 3 колекції Державного науково-контрольного інституту біотехнології і штамів мікроорганізмів (м. Київ). У якості препарату порівняння при оцінці антимікробної активності колоїдних розчинів наночастинок металів використовували хлоргексидин.

Безпечність колоїдних розчинів наночастинок срібла, золота і міді визначали в тестах in vitro за показниками цитотоксичності, генотоксичності, мутагенності, імунотоксичності та біохімічними маркерами згідно з критеріями Методичних рекомендацій «Оцінка безпеки лікарських нанопрепаратів», затверджених Науково-експертною радою державного експертного центру МО3 України (протокол № 8 від 26.09.2013 р.) [4].

Для обґрунтування складу і розробки технології косметичних засобів використано методи інформаційного пошуку, узагальнення даних літератури та технологічні методи.

Результати й обговорення. І. Обгрунтування вибору біологічно активних компонентів для розробки косметичних засобів

Для лікування або профрілактики ряду косметичних недоліків та дерматологічних захворювань шкіри часто необхідне застосування засобу з антимікробною дією, тому першим етапом наших досліджень було вивчення антимікробної активності колоїдних розчинів наночастинок срібла (AgNP), золота (AuNP) і міді (CuNP). Результати оцінки антимікробної активності колоїдних розчинів наночастинок металів відносно тестових штамів мікроорганізмів наведено в таблиці 1. Інтенсивність антимікробної дії порівнювали із хлоргексидином - відомим антисептичним засобом, який широко застосовують у медичній практиці, в тому числі у складі лікарських косметичних засобів $[5,6]$.

3 даних таблиці 1 видно, що присутність у середовищі визначення хлоргексидину у концентрації 5 мг/мл помірно пригнічувала ріст тест-штамів мікроорганізмів, тоді як наночастинки срібла і міді проявляли виражену бактерицидну дію. Наночастинки золота у виконаному дослідженні in vitro проявляли слабку антимікробну активність: відсутність вираженого пригнічення росту усіх тестових штамів мікроорганізмів.

3 огляду на високу біологічну активність наночастинок наступним етапом досліджень була характеристика їх безпечності.

Проведений комплекс in vitro досліджень згідно 3 Методичними рекомендаціями «Оцінка безпеки лікарських нанопрепаратів» [4] засвідчив, що синтезовані колоїдні розчини наночастинок срібла, міді і золота характеризувалися як безпечні за критеріями цитотоксичності, генотоксичності, мутагенності, а також у біохімічних та імунологічних тестах.

Отримані результати щодо рівня безпеки досліджених наночастинок свідчать про доцільність досліджень щодо їх подальшого медико-біологічного використання.

II. Обґрунтування вибору косметичних засобів для розробки

Гель для догляду за жирною шкірою

Проблеми жирної шкіри та акне на даний час $€$ дуже поширеними, тому розробка нових інновацій-

Таблиця 1. Ріст тест-штамів у присутності в середовищі визначення колоїдних розчинів наночастинок срібла, міді і золота порівняно із хлоргексидином

\begin{tabular}{|c|c|c|c|c|c|}
\hline Тест-штам & $\begin{array}{c}\text { Ріст тест-штамів } \\
\text { у присутності } \\
\text { хлоргекси- } \\
\text { дину в } \\
\text { середовищі } \\
\text { визначення у } \\
\text { концентрації } \\
5 \text { мг/мл }\end{array}$ & $\begin{array}{c}\text { Ріст тест-штамів } \\
\text { у присутності } \\
\text { АgNP у } \\
\text { середовищі } \\
\text { визначення в } \\
\text { концентрації } \\
\text { 0,16 мг/мл за } \\
\text { металом }\end{array}$ & $\begin{array}{c}\text { Ріст тест-штамів } \\
\text { у присутності } \\
\text { CuNP у } \\
\text { середовищі } \\
\text { визначення в } \\
\text { концентрації } \\
\text { 3,2 мг/мл за } \\
\text { металом }\end{array}$ & $\begin{array}{c}\text { Ріст тест-штамів } \\
\text { у присутності } \\
\text { АuNP у } \\
\text { середовищі } \\
\text { визначення в } \\
\text { концентрації } \\
\text { 38,6 мкг/мл за } \\
\text { металом }\end{array}$ & $\begin{array}{c}\text { Контроль- } \\
\text { ний ріст } \\
\text { тест-штаму }\end{array}$ \\
\hline $\begin{array}{l}\text { Staphylococcus } \\
\text { aureus }\end{array}$ & + & ріст відсутній & ріст відсутній & +++ & ++++ \\
\hline Escherichia coli & +++ & ріст відсутній & ріст відсутній & ++++ & ++++ \\
\hline $\begin{array}{l}\text { Pseudomonas } \\
\text { aeruginosa }\end{array}$ & + & ріст відсутній & ріст відсутній & +++ & ++++ \\
\hline Proteus vulgaris & + & ріст відсутній & ріст відсутній & ++++ & ++++ \\
\hline Candida albicans & ++ & ріст відсутній & ріст відсутній & +++ & ++++ \\
\hline
\end{tabular}

Примітка:

«++++»- інтенсивний ріст тест-штаму;

«+++» - слабо виражене пригнічення росту тест-штаму порівняно з контролем;

«++» - помірне пригнічення росту тест-штаму порівняно з контролем;

«+»- ріст лише поодиноких колоній на чашці.

ISSN 2312-0967. Фармацевтичний часопис. 2018. № 4 
них, ефективних та безпечних косметичних засобів для догляду за жирною шкірою надзвичайно актуальною.

Оскільки при виникненні акне особливу роль відіграє Propionibacterium acnes та стафрілококи, до складу косметичних засобів, спрямованих на подолання цієї проблеми, обов'язково повинні входити компоненти, які проявляють протимікробну дію. Також позитивний вплив на жирну та схильну до появи акне шкіру мають олії, що містять ненасичені жирні кислоти [7].

Найоптимальнішою фрормою косметичного засобу для жирної шкіри $є$ гелі 3 доброю очищувальною дією, вони нормалізують виділення шкірного сала та не пересушують шкіру. Гелі не залишають жирного блиску, утворюють тонку захисну плівку на поверхні шкіри і здатні пролонгувати дію лікарських речовин. Гелі мають гарний естетичний вигляд, добре наносяться і легко змиваються зі шкіри; не можуть проникати у шкіру через велику молекулярну масу гелеутворювальних речовин [8].

Враховуючи особливості жирної шкіри та високу біологічну активність наночастинок металів [1, 2], при розробці косметичного засобу у формі гелю для догляду за жирною шкірою ми використали як активні компоненти розчини наночастинок срібла та міді у концентраціях 0,2 мг/мл та 0,32 мг/мл за металом відповідно, які проявляють антимікробну дію, а також олію амаранту, у складі якої переважають ненасичені жирні кислоти, більшу частину з яких складає лінолева кислота. Крім того, олія амаранту містить сквален - важливий компонент шкіри людини, підвищує її захисні властивості, має протизапальну, регенеруючу та живильну дії.

\section{Крем для догляду за старіючою шкірою}

Історія застосування золота в медицині та косметології досить тривала. ще у середні віки вчені намагались створити «еліксир» із золота, який би міг повертати людині молодість і здоров'я [9]. Ідею введення золота в медичну практику приписують Парацельсу, який свого часу проголосив, що «не перетворення металів в золото повинно бути метою хімії, а приготування ліків». Відомий алхімік і хімік Парацельс готував ліки із мінералів, які містили метали, включно золото [10].

У косметології золото застосовують з метою одержання ефекту омолодження. Так, наприклад, найтонші нитки $з$ даного металу завдовжки всього кілька мікронів за допомогою спеціального провідника вводяться під шкіру. Через кілька тижнів навколо кожної з них формується еластична колагенова тканина, яка стає «каркасом» для шкіри. Золоті нитки біосумісні 3 тканинами організму і здатні сприяти ряду корисних реакцій у шкірі. Іони золота, які вивільняються при цьому, стимулюють мікроциркуляцію, збагачують клітини киснем. За рахунок поліпшення обмінних процесів у дермі починає вироблятись колаген та елас-
Фармацевтична технологія, біофармація, гомеопатія

Pharmaceutical technology, biopharmacy, homeopathy

тин, йде накопичення гіалуронової кислоти, яка відповідає за насичення шкіри вологою [11]. Золото $€$ потужним антиоксидантом, зв'язує і виводить вільні радикали, які 3 віком утворюються в шкірі і спричиняють старіння [9].

Високою біологічною активністю та біосумісністю характеризуються сореричні наночастинки золота певного розмірного діапазону. Зокрема, вони проявляють виражений протизапальний ефект та здатні ефрективно стимулювати регенерацію тканин [3, 9, 12]. Отже, розробка крему з наночастинками золота $\epsilon$ важливою для косметології 3 метою одержання еоректу омолодження без травматичних хірургічних втручань. Для розробки косметичного крему ми використали як активний компонент водну дисперсію сореричних наночастинок золота 3 концентрацією 77,2 мкг/мл за металом.

Оптимальним видом крему 3 «antiaging» ефректом для догляду за старіючою шкірою $€$ емульсійний крем типу вода/масло (в/м). Такий емульсійний крем має добрі захисні властивості; створює на шкірі шар, подібний до природного захисного шару; сприяє утриманню вологи в шкірі; потребує застосування меншої кількості консервантів. Емульсійні системи типу в/м характеризуються високим вмістом жирових компонентів - від 30 до 70 \%, а кількість водної фрази обмежена до 30-50 \%. Жирові компоненти таких кремів покривають шкіру тонкою водонепроникною плівкою, а за рахунок емолентів пом'якшують шкіру [13].

Бальзам для губ з антигерпетичною дією

Герпетичне ураження губ на даний час $є$ дуже поширеним. Ця косметична проблема найчастіше зустрічається як чоловіків, так і жінок. За статистикою майже 90 \% населення світу інфріковані вірусом простого герпесу $[14,15,16]$, тому розробка інноваційних засобів антигерпетичної дії для догляду за губами $є$ актуальною.

При виготовленні косметичного засобу для догляду за губами обрано фрорму бальзаму у вигляді олівця. Дана форма косметичного засобу є інноваційною, оскільки антигерпетичні засоби на сучасному фармацевтичному ринку представлені, в основному, у вигляді кремів та мазей.

Бальзам для губ, на відміну від мазей та кремів, не залишає слідів, тому при нанесенні виглядає більш естетично, що є дуже важливим для молодих людей працездатного віку, які часто страждають від герпетичних висипань на губах та мають відвідувати навчання чи ходити на роботу, що створює їм певний дискомфорт [16]. Перевагою бальзаму також $є$ і те, що він утворює тонку захисну плівку на поверхні шкіри губ і здатний пролонгувати дію активних компонентів.

На відміну від крему чи мазі з антигерпетичною дією бальзам для губ можна нанести на усю поверхню шкіри губ з метою профрілактики подальшого поширення герпетичних висипань. Форма бальзаму у

ISSN 2312-0967. Pharmaceutical review. 2018. № 4 
Фармацевтична технологія, біофармація, гомеопатія Pharmaceutical technology, biopharmacy, homeopathy

вигляді олівця є більш гігієнічною в плані нанесення на губи та більш зручною для застосування.

Враховуючи дані наукової літератури щодо наявності в наночастинок срібла і золота вираженої антивірусної дії $[17,18,19,20]$ як біологічно активний компонент при розробці бальзаму для губ ми використали колоїдний розчин наночастинок срібла і золота 3 концентрацією $\mathrm{C}_{\mathrm{Ag}}$ 4,0 мг/мл та $\mathrm{C}_{\mathrm{Au}}$ 0,15 мг/мл за металом.

Бальзам для губ з антигерпетичною дією, окрім противірусної дії, буде проявляти також протимікробну, захисну та зволожувальну дію, покращувати природний колір губ.

III. Обґрунтування складу, розробка технології та дослідження косметичних засобів

Створення косметичного гелю передбачає використання комплексу допоміжних інгредієнтів, які забезпечують одержання косметичної форми, необхідні косметичні та споживчі властивості, фрізичну, хімічну та мікробіологічну стабільність протягом терміну придатності.

Найважливішими компонентами гелів, вибір яких потребує обґрунтування та експериментальних досліджень, $є$ гелеутворювачі та стабілізатори емульсії.

Як гелеутворювачі ми використали природні та синтетичні гелеутворювачі, зокрема карбопол, полоксамер та камедь гуарова. Враховуючи антимікробну активність наночастинок срібла та міді, консерванти у складі гелів не застосовували. Склади гелів наведено у таблиці 2.

Технологія більшості гелевих основ передбачає розчинення гелеутворюючих речовин при нагріванні 3 наступним гелеутворенням при охолодженні [8, $13,21]$. Таким чином готували гелі на основі полоксамеру та камеді гуарової. Холодні гелі, одержані шляхом набухання гелеутворюючої речовини в розчиннику, готують на основі карбополу [8]. Приготування гелів карбополу є особливим, оскільки гелеут- ворення наступає після зміни $\mathrm{pH}$ розчину карбополу до нейтральної величини $[8,13]$. При виготовленні гелевих основ особлива увага приділяється їх стабільності. Такі явища, як старіння гелів та їх коагуляційний розпад значною мірою залежать від технологічного процесу.

У результаті досліджень органолептичних та фрізико-хімічних показників гелів відповідно до Державного стандарту України «Креми косметичні» [22] встановлено, що гелі 3 наночастинками срібла мають темний колір, отже за споживчими характеристиками не відповідають вимогам до косметичних засобів, тому у подальшому їх можна вивчати як лікарські засоби.

У гелях на основі карбополу під впливом наночастинок металів відбувається руйнування гелевої структури при зберіганні. Гелі на основі природного гелеутворювача камеді гуарової виявились мікробіологічно нестабільними при зберіганні, що вказує на необхідність введення до їх складу консерванту.

Як перспективний косметичний засіб ми вибрали гель із наночастинками міді та олією амаранту на основі полоксамеру, який має приємний колір з легким голубим відтінком і $є$ стабільним при зберіганні без введення консерванту.

Розробка гелю 3 наночастинками міді та олією амаранту буде сприяти розширенню номенклатури інноваційних косметичних засобів для догляду за жирною шкірою, які будуть проявляти антимікробну дію на жирну шкіру та підвищувати її захисні властивості.

Створення косметичного крему передбачає використання комплексу інгредієнтів, які забезпечують одержання косметичної форми, необхідних косметичних та споживчих властивостей, фрізичну, хімічну та мікробіологічну стабільність протягом терміну їх придатності. Проте найважливішими компонентами

Таблиця 2. Склади гелів із наночастинками $\mathrm{Ag}$ та Cu та олією амаранту

\begin{tabular}{|c|c|c|c|c|c|c|}
\hline Компоненти гелю & Склад № 1 & Склад № 2 & Склад № 3 & Склад № 4 & Склад № 5 & Склад № 6 \\
\hline $\begin{array}{l}\text { Розчин наносрібла } \\
\left(\mathrm{C}_{\mathrm{Ag}}=4,0 \text { мг /мл) }\right.\end{array}$ & 5 мл & 5 мл & 5 мл & - & - & - \\
\hline $\begin{array}{l}\text { Розчин наноміді } \\
\left(\mathrm{C}_{\mathrm{Cu}}=32,0 \text { мг /мл) }\right.\end{array}$ & - & - & - & 1 мл & 1 мл & $1 \mathrm{мл}$ \\
\hline Олія амаранту & 5,0 & 5,0 & 5,0 & 5,0 & 5,0 & 5,0 \\
\hline Карбопол & 0,2 & - & - & 0,2 & - & - \\
\hline Полоксамер & - & 30,0 & - & - & 30,0 & - \\
\hline Камедь гуара & - & - & 1,5 & - & - & 1,5 \\
\hline Гліцерин & 5,0 & - & - & 5,0 & - & - \\
\hline Розчин аміаку 25\% & до рН 6.0 & - & - & до рН 6.0 & - & - \\
\hline Хостацерину & 2,5 & - & - & 2,5 & - & - \\
\hline Полісорбат 20 & - & 0,1 & 0,1 & - & 0,1 & 0,1 \\
\hline Вода очищена & до 100,0 & до 100,0 & до 100,0 & до 100,0 & до 100,0 & до 100,0 \\
\hline
\end{tabular}

ISSN 2312-0967. Фармацевтичний часопис. 2018. № 4 
емульсійного крему, вибір яких потребує обґрунтування та експериментальних досліджень, є емоленти та стабілізатори емульсії [8].

Ми дослідили 3 склади кремів із колоїдним розчином золота на емульсійних основах типу в/м (табл. 3).

У складі кремів із наночастинками золота як емоленти ми використали олії оливкову, кукурудзяну та виноградних кісточок, вазелін, а також ланолін та спирт цетостериловий, які виконують функції емолента та стабілізатора.

При виготовленні косметичного крему застосовували технологічні правила і прийоми, характерні для технології м'яких лікарських засобів [8].

У результаті досліджень органолептичних та фрізико-хімічних показників кремів відповідно до Державного стандарту України «Креми косметичні» [22] встановлено, що оптимальним $€$ крем № 2 наступного складу: колоїдний розчин наночастинок золота, спирт цетостериловий, ланолін безводний, вазелін, вода очищена, олія оливкова, олія виноградних кісточок та полісорбат 80, який є стабільним за всіма досліджуваними показниками. Крем має білий колір, легко наноситься, рН крему знаходиться в межах рН здорової шкіри.
Фармацевтична технологія, біофармація, гомеопатія Pharmaceutical technology, biopharmacy, homeopathy

Розробка крему з наночастинками золота буде сприяти розширенню номенклатури інноваційних косметичних засобів для догляду за старіючою шкірою.

Незважаючи на велику номенклатуру сучасних косметичних інгредієнтів, основними компонентами, на яких базується склад косметичного засобу у фрормі бальзаму для губ, залишаються тверді жири і воски, рослинні та ефрірні олії. Завдяки твердим жирам і воскам губи надійно захищені, а також завдяки емульгуючим властивостям воску можна вводити до складу бальзаму водні компоненти. Призначення рослинної олії сприяє зниженню небезпеки появи тріщин. Зазвичай у бальзамах для губ застосовують тверді жирові основи та олію рослинну у співвідношенні 1:2 [13]. Ефрірні олії надають бальзамам для губ лікувальних властивостей або підсилюють дію інших біологічно активних речовин. Як допоміжні компоненти у складі бальзаму ми обрали віск бджолиний, парафрін, гліцерину моностеарат, масло кокосове, масло какао, вазелін, олія оливкова та ефрірні олії ялівцю і троянди. Розроблено 3 склади бальзаму, які відрізняються складом та концентрацією допоміжних компонентів (табл. 4).

Таблиця 3. Склади кремів з наночастинками золота

\begin{tabular}{|l|c|c|c|}
\hline \multirow{2}{*}{ Компоненти } & \multicolumn{2}{|c|}{ Кількість компонентів, г } \\
\cline { 2 - 4 } & Склад № 1 & Склад № 2 & Склад № 3 \\
\hline Спирт цетостериловий & - & 3,5 & 2,5 \\
\hline Ланолін безводний & 5,0 & 2,5 & 2,5 \\
\hline Вазелін & 20,0 & 2,5 & 20,0 \\
\hline Олія оливкова & - & 20,0 & 5,0 \\
\hline Олія виноградних кісточок & - & 5,0 & - \\
\hline Олія кукурудзяна & 41,5 & - & 0,5 \\
\hline Твін-8о & - & 1,5 & - \\
\hline Віск бджолиний & 3,5 & - & 0,5 \\
\hline Р-н наночастинок & 1,0 & 0,5 & до 100,0 \\
\hline Вода очищена & до 100.0 & до 100.0 \\
\hline
\end{tabular}

Таблиця 4. Склади бальзамів для губ

\begin{tabular}{|l|c|c|c|}
\hline Назва компонента & Склад № 1 & Склад № 2 & Склад № 3 \\
\hline Віск бджолиний & 3,0 & & 3,0 \\
\hline Парасрін & & & \\
\hline Моностеарат гліцерину & & 3,0 & 5,0 \\
\hline Олія оливкова & 5,0 & 5,0 & 1,0 \\
\hline Олія кокосова & 1,0 & & \\
\hline Олія какао & & 1,0 & 5 крапель \\
\hline Вазелін & & 5 крапель & крапель \\
\hline Олія ялівцева & 5 крапель & 5 крапель & 1 мл \\
\hline Олія трояндова & 5 крапель & 1 мл & 1 мл \\
\hline Колоїдний розчин наночастинок срібла і золота & & & \\
\hline
\end{tabular}

ISSN 2312-0967. Pharmaceutical review. 2018. № 4 
Фармацевтична технологія, біофармація, гомеопатія Pharmaceutical technology, biopharmacy, homeopathy

Оскільки за типом дисперсних систем розроблена композиція належить до емульсійних систем, технологія бальзаму передбачає стадію емульгування колоїдного розчину наночастинок.

У жировій основі бальзаму відсутня міжфазна поверхня, тому приготування жирової основи передбачає приготування сплаву (віск бджолиний, олія кокосова, олія оливкова).

Гідрофрільну фразу (колоїдний розчин наночастинок срібла та золота) емульгують 3 жировою основою, суміш охолоджують до $40-45^{\circ} \mathrm{C}$, а потім додають ефрірні олії. Отриману масу добре перемішують та розливають у форми.

Якість бальзамів для губ оцінювали за органолептичними та фрізико-хімічними показниками відповідно до ДСТУ 4774:2007 «Вироби косметичні для макіяжу на жировосковій основі» [23]. У результаті технологічних досліджень встановлено, що бальзам, до складу якого входять колоїдний розчин наночастинок срібла і золота, віск бджолиний, олія оливкова, олія кокосова, олія ялівцева та олія трояндова, проявляє кращі споживчі характеристики за органолептичними показниками, тому цей склад обрали для подальших досліджень.

Розроблений бальзам буде сприяти розширенню номенклатури косметичних засобів для догляду за губами з герпетичним ураженням, проявляти антивірусну дію на шкіру губ та підвищувати ії захисні властивості.

Висновки. На основі комплексу досліджень in vitro вивчено антимікробну активність колоїдних розчинів наночастинок срібла, міді і золота та досліджено безпечність їх застосування в складі косметичних засобів. Обґрунтовано склад, розроблено технологію та проведено дослідження трьох косметичних засобів: гелю з наночастинками міді для догляду за жирною шкірою, крему з наночастинками золота для догляду за старіючою шкірою та бальзаму для губ 3 антигерпетичною дією 3 наночастинками золота і срібла. Одержані результати показують перспективність подальших досліджень нових косметичних засобів на основі наночастинок металів.

\section{ИССЛЕДОВАНИЯ ПО РАЗРАБОТКЕ КОСМЕТИЧЕСКИХ СРЕДСТВ НА ОСНОВЕ НАНОЧАСТИЦ СЕРЕБРА, ЗОЛОТА И МЕДИ}

\section{С. Б. Билоус ${ }^{1}$, С. М. Дыбкова ${ }^{2,3}$, Л. С. Резниченко ${ }^{2,3}$}

Львовский национальный медицинский университет имени Данила Галицкого ${ }^{1}$

Институт биоколлоидной химии имени Ф. Д. Овчаренко НАН Украины ${ }^{2}$

Институт ветеринарной медицины НААН Украины ${ }^{3}$

svitlana.bilous@gmail.com

Цель работы. Обосновать состав и технологию перспективных косметических средств с наночастицами серебра, золота и меди.

Материалы и методы. Для разработки косметических средств использовали коллоидные растворы наночастиц серебра, золота и меди, синтезированные в Институте биоколлоидной химии имени Ф. Д. Овчаренко НАН Украины. Антимикробную активность коллоидных растворов наночастиц металлов в исследованиях in vitro определяли методом серийных разведений в агаре. Безопасность коллоидных растворов наночастиц серебра, золота и меди определяли в тестах in vitro по показателям цитотоксичности, генотоксичности, мутагенности, иммунотоксичности и биохимическим маркерам. Для обоснования состава и технологии косметических средств использованы методы инорормационного поиска, анализа данных литературы и технологические исследования.

Результаты и обсуждение. Результаты оценки антимикробной активности коллоидных растворов наночастиц металлов показали, что наночастицы серебра и меди проявляют выраженное бактерицидное действие, а наночастицы золота - слабую антимикробную активность. Относительно уровня безопасности исследованных наночастиц, результаты свидетельствуют о безопасности и целесообразности их дальнейшего медико-биологического использования. Учитывая особенности требований к внедрению на рынок косметических средств по сравнению с лекарственными препаратами, в частности отсутствие обязательных требований к проведению качественного и количественного анализа наночастиц в косметическом средстве, а только необходимость проведения санитарногигиенической экспертизы, определены перспективы наночастиц металлов как биологически активных компонентов косметических средств. Обоснованы состав и технология геля для ухода за жирной кожей, в котором как активные компоненты использованы раствор наночастиц меди и масло амаранта, крема для ухода за стареющей кожей с наночастицами золота и бальзама для губ с антигерпесным действием на основе наночастиц серебра и золота.

Выводы. Полученные результаты показывают перспективность дальнейших исследований косметических средств на основе наночастиц металлов, что будет способствовать расширению номенклатуры инновационных косметических средств.

Ключевые слова: косметические средства; наночастицы серебра; наночастицы золота; наночастицы меди.

ISSN 2312-0967. Фармацевтичний часопис. 2018. № 4 


\title{
THE STUDIES ON THE DEVELOPMENT OF COSMETIC PRODUCTS ON THE BASIS OF SILVER, GOLD AND COPPER NANOPARTICLES
}

\author{
S. B. Bilous ${ }^{1}$, S. M. Dybkova ${ }^{2,3}$, L. S. Rieznichenko ${ }^{2,3}$ \\ Danylo Halytsky Lviv National Medical University ${ }^{1}$ \\ F. Ovcharenko Institute of Biocolloidal Chemistry of the NAS of Ukraine ${ }^{2}$ \\ Institute of Veterinary Medicine of the NAAS of Ukraine ${ }^{3}$ \\ svitlana.bilous@gmail.com
}

The aim of the work. To substantiate the composition and technology of perspective cosmetics with silver, gold and copper nanoparticles.

Materials and Methods. Colloidal solutions of silver, gold and copper nanoparticles synthesized in F. D. Ovcharenko Institute of Biocolloidal Chemistry of the National Academy of Sciences of Ukraine were used to develop cosmetic products. Antimicrobial activity of colloidal solutions of metals nanoparticles in vitro was determined by serial dilutions in agar. The safety of colloidal solutions of silver, gold and copper nanoparticles was determined in in vitro tests by indexes of cytotoxicity, genotoxicity, mutagenicity, immunotoxicity and biochemical markers. Methods of information retrieval, analysis of literature data and technological research were used to substantiate the composition and technology of cosmetic products.

Results and Discussion. Results of the metal nanoparticles' antimicrobial activity estimation showed that silver and copper nanoparticles exhibit pronounced bactericidal action, gold nanoparticles have a weak antimicrobial activity. As to the level of safety of investigated nanoparticles, the studies indicate the safety and expediency of their subsequent medical and biological use.

Taking into account the peculiarities of the requirements for the introduction of cosmetic products into the market in comparison with medicinal preparations, in particular the absence of mandatory requirements for qualitative and quantitative analysis of nanoparticles in a cosmetic product, only the need of sanitary hygienic examination, the prospects of metals nanoparticles as biologically active components of cosmetics determined. The composition and technology of the gel for oily skin care, in which as active components a solution of copper nanoparticles and Amaranth oil were used, cream for the aging skin care with gold nanoparticles and lip balm with anti-herpes action based on silver and gold nanoparticles were substantiated.

Conclusions. The obtained results show the prospect of further study of cosmetics based of metals nanoparticles, what will promote the expansion of the nomenclature of innovative cosmetic products.

Key words: cosmetics; silver nanoparticles; gold nanoparticles; copper nanoparticles.

\section{Список літератури}

1. Role of nanotechnology in cosmeceuticals: A review of recent advances / S. Kaul, N. Gulati, D. Verma [et al.] // Journal of Pharmaceutics. - 2018. - Article ID 3420204 . 19 p. https://doi.org/10.1155/2018/3420204

2. Gajbhiye S. Silver nanoparticles in cosmetics / S. Gajbhiye, S. Sakharwade // Journal of Cosmetics, Dermatological Sciences and Applications. - 2016. - Vol. 6. - P. 48-53. http://dx.doi.org/10.4236/jcdsa.2016.61007

3. Fernandesde R. Anti-inflammatory, analgesic and antitumor properties of gold nanoparticles / R. Fernandesde, A. Júnior // Pharmacological Reports. - 2017. - Vol. 69 (1). - P. 119-129

4. Методичні рекомендації «Оцінка безпеки лікарських нанопрепаратів» / Розробн. : І. М. Трахтенберг, 3. Р. Ульберг, І. С. Чекман [та ін.]. - Київ, 2013. - 108 с.

5. Reducing the risk of surgical site infections: Does chlorhexidine gluconate provide a risk reduction benefit? / Ch. E. Edmiston, B. Bruden, M. C. Rucinski, C. Henen [et al.] // Americal Journal of Infection Control. - 2013. Vol. 41. - P. 49-55.

6. Efficacy of chlorhexidini gluconate ointment (Oronine $\mathrm{H}^{\circledR}$ ) for experimentally-induced comedones / T. Yamakoshi, T. Makino, K. Matsunaga, Y. Yoshihisa [et al.] // Clinical, Cosmetic and Investigatinal Dermatology. - 2012. - Vol. 5. - P. 79-83.
7. Cosmetic dermatology / Edited by Z. D. Draelos. - Wiley-Blackwell publishing, 2010. -550 p.

8. Практикум 3 технології лікарських косметичних засобів / Т. Г. Калинюк, Є. В. Бокшан, С. Б. Білоус та ін. - К. : Медицина, 2008 . - 184 с.

9. Чекман І.С. Нанозолото та нанопокриття із золота: стан наукових досліджень, перспективи застосування у медицині / I. С. Чекман, А. О. Прискока // Укр. мед. часопис. - 2010. - № 2 (76). - С. 37-43.

10. Башура А. Г. История косметологии и аромологии: конспект лекций /А. Г. Башура, А. С. Зуева. - Х. : Изд-во НФаУ; Золотые страницы, 2004. - 156 с.

11. Папий Н. А. Медицинская косметология / Н. А. Папий, Т. Н. Папий. - Москва, 2008. - 512 с.

12. Gold nanoparticles promote proliferation of human periodontal ligament stem cells and have limited effects on cells differentiation / C. Li, Zh. Li, Y. Wang, H. Liu // Journal of Nanomaterials. - Vol. 2016. - Article ID 1431836. - 10 p. http://dx.doi.org/10.1155/2016/1431836

13. Технологія косметичних засобів: навч. посіб. для студ. фрармац. спец. вищ. навч. закл. / О. Г. Башура, Н. П. Половко, Т. М. Ковальова та ін. - Вінниця : Нова книга, 2007. - 360 с.

14. Герпесвирусная инфрекция: диагностика, клиника, лечение / Под ред. Ю. К. Скрипкина. - М. : МИА, 2004. - 152 с.

ISSN 2312-0967. Pharmaceutical review. 2018. № 4 
Фармацевтична технологія, біофармація, гомеопатія Pharmaceutical technology, biopharmacy, homeopathy

15. Исаков В. А. Герпесвирусные инфекции человека : руководство для врачей / В. А. Исаков, Е. И. Архипова, Д. В. Исаков. - СПб. : СпецЛит, 2006. - С. 63-75.

16. Калюжна Л. Д. Хвороби шкіри обличчя, слизової оболонки ротової порожнини та червоної облямівки губ / Л. Д. Калюжна, Т. Ф. Білоклицька. - Київ, 2007. С. 147-156.

17. An overview application of silver nanoparticles in inhibition of herpes simplex virus / A. Akbarzadeh, L. Kafshdooz, Z. Razban, A. D. Tbrizi // Artificial Cells, Nanomedicine and Biotechnology. - 2017. http://dx.doi.or $\mathrm{g} / 10.1080 / 21691401.2017 .1307208$

18. Inhibition effect of silver nanoparticles on herpes simples virus 2 / R. L. Hu, S. R. Li, F. J. Kong [et al.] // Genetics and Molecular Research. - 2014. - Vol. 13 (3). P. $7022-7028$.

\section{References}

1. Kaul S, Gulati N, Verma D, Mukherjee S, Nagaich U. Role of nanotechnology in cosmeceuticals: A review of recent advances. Journal of Pharmaceutics. 2018; Article ID 3420204. https://doi.org/10.1155/2018/3420204

2. Gajbhiye S, Sakharwade S. Silver nanoparticles in cosmetics. Journal of Cosmetics, Dermatological Sciences and Applications. 2016;6: 48-53.

3. Fernandesde R, Júnior A. Anti-inflammatory, analgesic and anti-tumor properties of gold nanoparticles. Pharmacological Reports. 2017;69(1): 119-29.

4. Trakhtenberh IM, Ulberh ZR, Chekman IS. Methodical recommendations Assessment of the safety of medical nanoparticles. [Методичні рекомендації «Оцінка безпеки лікарських нанопрепаратів»] Kyiv; 2013. Ukrainian.

5. Edmiston CE, Bruden B, Rucinski MC, Henen C. Reducing the risk of surgical site infections: Does chlorhexidine gluconate provide a risk reduction benefit? Americal journal of infection control. 2013;41: 49-55.

6. Yamakoshi T, Makino T, Matsunaga K, Yoshihisa Y. Efficacy of chlorhexidini gluconate ointment (Oronine $\mathrm{H}^{\circledR}$ ) for experimentally-induced comedones. Clinical, Cosmetic and Investigatinal Dermatology. 2012;5: 79-83.

7. Draelos ZD. Cosmetic dermatology. Wiley-Blackwell publishing; 2010.

8. Kalyniuk TH, Bokshan YeV, Bilous SB. Practice on technology of medicinal cosmetics. [Практикум 3 технології лікарських косметичних засобів] Kyiv: Medytsyna; 2008. Ukrainian.

9. Chekman IS, Pryskoka AO. [Nanogold and gold nanocoating: state of scientific research, prospects of application in medicine]. Ukr Med Chasopys 2010;2(76): 37-43. Ukrainian.

10. Bashura $A H$, Zueva AS. History of cosmetology and aromatology. [История косметологии и аромологии: Конспект лекций] Kharkiv: Zolotistorinky; 2004. Ukrainian. 11. Papyi NA, Papyi TN. Medicinal cosmetology. [Медицинская косметология] Moscow; 2008. Russian. 12. Li C, Li Zh, Wang Y, Liu H. Gold nanoparticles promote proliferation of human periodontal ligament stem cells and have limited effects on cells differentiation. Journal of Nanomaterials. 2016; ID 1431836. http://dx.doi. org/10.1155/2016/1431836
19. Tannic acid modified silver nanoparticles show antiviral activity in herpes simplex virus type 2 infection / P. Orlowski, E. Tomaszewska, M. Gniadek [et al.] // Plos One. - 2014. Vol. 9. Iss. 8. e104113. www.plosone.org

20. Highly monodispersed gold nanoparticles synthesis and inhibition of herpes simplex virus infections / A. Halder, S. Das, D. Ojha [et. al.] // Materials Science and Engineering. - 2018. - Vol. 89. - P. 413-421.

21. Фармацевтичні та медико-біологічні аспекти ліків : навч. посіб. / За ред. І. М. Перцева. - Вінниця : НОВА КНИГА, 2007. - 728 с.

22. Креми косметичні : ДСТУ 4765:2007 (Національний стандарт України). - К. : Держспоживстандарт України, 2008. - 7c

23. Вироби косметичні для макіяжу на жировосковій основі : ДСТУ 4774:2007. - Київ, 2009. - 14 с.

13. Bashura OH, Polovko NP, Kovalova TM. Cosmetic technology. [Технологія косметичних засобів: навч. посібник для студ. фрармац. спец. вищ. навч. заклад.] Vinnytsia: Nova knyha; 2007. Ukrainian.

14. Skrypkyn Yu.K. Herpes virus infection: diagnosis, clinic, treatment. [Герпесвирусная инорекция: диагностика, клиника, лечение] Moscow: MYA; 2004. Russian.

15. Isakov VA, Arkhypova EY, Isakov DV. Herpes virus infection: diagnosis, clinic, treatment. [Герпесвирусные иноекции человека: Руководство для врачей]. Saint Petersburg: SpetsLyt; 2006. Russian.

16. Kaliuzhna LD, Biloklytska TF. Diseases of the skin of face, the mucous membrane of oral cavity and lips. [Хвороби шкіри обличчя, слизової оболонки ротової порожнини та червоної облямівки губ] Kyiv; 2007. Ukrainian.

17. Akbarzadeh A, Kafshdooz L, Razban Z, Tbrizi AD et al. An overview application of silver nanoparticles in inhibition of herpes simplex virus. Artificial cells, nanomedicine and biotechnology. 2017. http://dx.doi.org/10.1080/21691401.2017.1307208 18. Hu RL, Li SR, Kong FJ et al. Inhibition effect of silver nanoparticles on herpes simplex virus 2. Genetics and Molecular Research. 2014;13 (3): 7022-28.

19. Orlowski P, Tomaszewska E, Gniadek M, Baska P. et al. Tannic acid modified silver nanoparticles show antiviral activity in herpes simplex virus type 2 infection. Plos One. 2014; 9. 8. e104113. www.plosone.org

20. 20. Halder A, Das S, Ojha D, Chattopadhyay D et. al. Highly monodispersed gold nanoparticles synthesis and inhibition of herpes simplex virus infections. Materials Science and Engineering. 2018;89: 413-21.

21. Pertsev IM. Pharmaceutical and medico-biological aspects of medicines. [Фармацевтичні та медико-біологічні аспекти ліків. Навчальний посібник] Vinnytsia: Nova knyha; 2007. Ukrainian.

22. Cosmetic creams. National standard of Ukraine. [Креми косметичні: ДСТУ 4765:2007. Національний стандарт України] Kyiv: Derzhspozhyvstandart Ukrainy; 2008. Ukrainian. 23. Cosmetic products on fat-wax base. [Вироби косметичні для макіяжу на жировосковій основі. ДСТУ 4774:2007] Kyiv; 2009. Ukrainian.

Отримано 18.09.2018

ISSN 2312-0967. Фармацевтичний часопис. 2018. № 4 